ISSN 1991- 8690

website : http:// jsci.utq.edu.iq

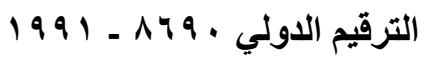

Email: utjsci@utq.edu.iq

\title{
Determination of Indoor Radon Concentration in Thi Qar Province Houses by using CR-39 SSNTD
}

\author{
Jabbar M. Rashid \\ Department of Physics-College of science- Thi Qar University
}

\begin{abstract}
The possible detrimental health effects of the inhaled radon and its decay products are in the limelight of interest of professionals as well as of the public. In the present work the passive integrated dosimeter technique with solid state nuclear track detectors (SSNTDs) super grade CR-39, was used to measure the concentration of the radioactive radon gas (Rn-222) indoor for 12 different locations in Thi Qar province. 176 detectors $(1.0 \mathrm{~cm} \times 1.0 \mathrm{~cm} \times 0.5 \mathrm{~cm})$ were prepared and were distributed in the chosen locations, after 90 days ( November, December 2012 and January 2013) the detectors were collected and treated chemically using etching conditions which controlled by four principals variables ( etching solutions ,temperature, morality and etching time). The tracks per unit area in each detector were determined by using MICROS Crocus II MCX100LCD optical microscope. Results obtained showed that radon average concentration indoors was varies from $25.66 \mathrm{~Bq} / \mathrm{m}^{3}$ in Bateha to $113.63 \mathrm{~Bq} / \mathrm{m}^{3}$ in Fuhood, and the annual effective dose according to these concentrations are $0.890 \mathrm{mSv} / \mathrm{y}$ and $3.941 \mathrm{mSv} / \mathrm{y}$ respectively. Results indicate that the houses surveyed had indoor radon levels within permissible level when ICRP1993 recommended limit of $600 \mathrm{Bqm}^{-3}$ was used. Few houses had higher radon levels if NRPB (Health Protection agency) UK and US (environmental protection agency) EPA limits of 200 and $148 \mathrm{~Bq} \mathrm{~m}^{-3}$ were used. The overall average for the concentrations of radon in indoor air in the province of Thi Qar in this study is $66.989 \mathrm{~Bq} / \mathrm{m}^{3}$ with a standard deviation of 48.554 this concentration is less or asymptotic concentration of radon in most of the neighboring countries of Iraq.
\end{abstract}

Keywords: Radon, radon concentration, CR-39 detector, SSNTD detectors

$$
\begin{aligned}
& \text { CR- تحديد تراكيز غاز الرادون في الهواء داخل منازل r I مدينة في محافظة ذي قار باستخدام كاشف الاثر النووي } \\
& 39 \\
& \text { جبار ماضي راثند } \\
& \text { قسم الفيزياء - كلية العلوم- جامعة ذي قار }
\end{aligned}
$$


الفترة الزمنية جمع 117 منها حيث تمت معالجتها كيميائيا باستخدام محلول هيدروكسيد الصوديوم 7 ساعات .نظفت الكواشف بشكل جيد بالماء الاعتيادي و الماء المقطر ثم جفقت وصنفت .استخدم مجهر ضوئي كمبيوتري لحساب عدد الاثار لوحدة المساحة لكل كاشف على حدة (track/cm² ومن ثم ثم حساب تراكيز الرادون في كل منزل لكل مدينة باستخدام معامل المعايرة المحسوب عمليا في هذا البحث 0.00296 [Bq/m²day/tracks/m²] النتائج التي تم الحصول عليها تشير الى ان معدل تركيز غاز الرادون متباين بشكل واضح من 25.66  فعالة مقدارها 0.890 mSv/y في مدينة البطحة و mSv/y 3.94 في مدينة الفهود.نشير النتائج التي تم الحصول عليها الى ان مستوبات نركيز غاز الرادون في منازل جميع المدن تحت الدراسة هي ضمن الحدود المسموحه بالمقارنة مع توصيات

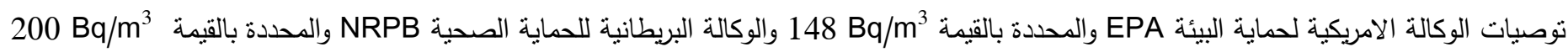
فان هناك بعض المنازل تتجاوزفيها مستويات نراكيز غاز الرادون توصيات الوكالتين. المعدل العام لتراكيز غاز الرادون في المحافظة هو Bq/m.989 بانحراف معياري قدره

\section{Introduction}

Radon is a chemically inert, radioactive, colorless and odorless gas that emanates from soil and rocks. Three radon is otopes ${ }_{219}^{222} \mathrm{Rn},{ }^{220} \mathrm{Rn}$, and ${ }^{219} \mathrm{Rn}$ are known, which are called radon, thoron and actinon, respectively. Radon is a descendant from the ${ }^{238} \mathrm{U}$ decay chain, while thoron is a descendant from the ${ }^{232} \mathrm{Th}$ decay chain and actinon is a descendant from the $\mathrm{U}$ decay chain. As thoron and actinon have very short half-lives of $55.6 \mathrm{~s}$ and $3.96 \mathrm{~s}$, respectively, comparing to the radon that has halflife of 3.82 days, they are very rare gases in the atmosphere. Radon has four short-lived progeny 218 $\mathrm{Po},{ }^{214} \mathrm{~Pb},{ }^{214} \mathrm{Bi}$, and ${ }^{214} \mathrm{Po}$. All methods of radon monitoring are based on the detection of either $\alpha$ particles or $\gamma$-rays emitted during the decays both of ${ }^{222} \mathrm{Rn}$ and its progeny [1]. Radon becomes a concern, however, when it seeps through openings such as cracks, loose fitting pipes, sump pits, dirt floors, slab joints or block walls and accumulates in the home. Air pressure inside the home is usually lower than pressure in the soil around the house's foundation. Because of this difference the house acts like a vacuum, drawing radon in through foundation cracks and other openings. Radon has been identified as a risk factor in developing lung cancer because it decays into radioactive particles that can get trapped in the lungs. These particles release bursts of energy that damages lung tissue. It is estimated that radon may be associated with about 21,100 lung cancer deaths per year in the United States, second only to smoking [2]. The chances of getting lung cancer from radon depend on how much radon is in the home, the amount of time spent in the home and whether a person smokes. Smoking, combined with radon, adds to the health risk. Because radon levels are influenced by a variety of factors soil type and moisture, how "tight" the home is, type of heating and ventilation system, movement of air and groundwater, air pressure, and lifestyle behavior of the occupants the only way to know if a home has elevated levels of radon is to test it [3]. Radon measurements show how much radon was present in the home during the test period. This level varies depending on detector location and the time of year it was used. As mentioned earlier, radon levels are generally highest when the house is closed and in the basement or near possible radon entry routes. Radon gas is measured in units of picocuries per liter $(\mathrm{pCi} / \mathrm{L})$ or $\mathrm{Bq} / \mathrm{m} 3$, a standard measure of radioactivity. The EPA set $4 \mathrm{pCi} / \mathrm{L}$ or $148 \mathrm{~Bq} / \mathrm{m} 3$ as a recommended action level. If a short-term measurement is over $148 \mathrm{~Bq} / \mathrm{m} 3$, the recommended action is to perform a follow-up test to better characterize the radon levels [4]. If a long-term test measures over $148 \mathrm{~Bq} / \mathrm{m} 3$, action should be taken to reduce radon exposure. The level of radon in a home may vary considerably from neighbor to neighbor. So the only way to know is to test. [5].

\subsection{Annual effective doses}

Determination of the Annual Effective Dose In order to estimate the annual effective doses indoors, taking into account the conversion coefficient from absorbed dose in air to effective dose and the indoor occupancy factor. In the (UNSCEAR (B), 2000) Report [6], a value of $9.0 \times 10-6 \mathrm{mSvh}-1$ per Bq/ $\mathrm{m} 3$ was used for the conversion factor, 0.4 for the equilibrium factor 
of Rn-222 indoors and 0.8 for the indoor occupancy factor. Calculating the annual effective dose to the population, the equation below is used (ICRP65, 1993) [7]. At a certain radon concentration $\mathrm{CRn}$ in $\mathrm{Bq} / \mathrm{m} 3$ the annual radon (absorbed) dose, DRn is usually expressed in the unit of $\mathrm{mSv}$ from the following relation:

$D_{R n}(m S v / y)=C_{R n}$ D.H.F.T

Where $\mathrm{CRn}$ is the measured $\mathrm{Rn}-222$ concentration (in Bqm-3), $\mathrm{F}$ is the $\mathrm{Rn}-222$ equilibrium factor indoors (0.4), $\mathrm{T}$ is the indoor occupancy time $[0.4 \mathrm{x}$ staying time in home per day) $\mathrm{x} 365=(\mathrm{)}) \mathrm{h}-1]$, and $\mathrm{D}$ is the dose conversion factor $(9.0 \times 10-6 \mathrm{mSv}$ h-1 per $\mathrm{Bq}$ m$3)$. Now to calculate the annual effective dose, one has to apply a tissue and radiation weighting factors according to ICRP65, 1993. The equivalent dose is the radiation-weighted absorbed dose. The radiation weighting (WR) factor for alpha particles is 20 as recommended by ICRP 1993, 1994. With the effective dose, a tissue weighting (WT) factor is applied. According to ICRP, the tissue weighting factor for lung is 0.12. The annual effective dose (Eaed) is then calculated according to the following equation (UNSCEAR (B), 2000) [6]:

$$
E_{\text {aed }}\left(m S v y^{-1}\right)=D_{R n} . W_{R} \cdot W_{T}
$$

Where, $\mathrm{DRn}=$ Annual Absorbed dose, WR = Radiation Weighting Factor for Alpha Particles, 20, WT $=$ Tissue Weighting Factor for the Lung 0.12 .It is, however, apparent that the time spent by individuals in the home varies widely. The occupancy factor of 0.8 (ICRP65,1993, 1994) [7] over estimates the excess lung cancer risk in the temperate regions but may be valid for the inhabitants of the Immoderate regions, where people spend most of their time in indoors.

\section{Materials and Methods}

\subsection{The study area (houses selection)}

In the present study, houses surveyed in the 12 city in Thi Qar province (Al Fajir (Faj), Al Qulah (Qul), Al Rifa'ay (Rif), Al Nasir (Nsr),Al Shatrah (Sha), Al Gharaf (Gha),Al Nasiriyah (Nas), (Suq)Al shiukh, Al Bateha (Bat), Al Fuhood (Fuh),Al Aslah (Asl) and Al Gibiesh (Gib)) were built from baked bricks and cement. Each room contained one or two windows. These included both single and double storey houses. Each house contained at least two rooms. Dosimeters were installed in a bedroom of each of the selected house. In the case of double storey houses, dosimeters were installed in bedroom located at the ground floor. All the houses surveyed were detached and semidetached houses. Dosimeters were installed at head height in bedroom of each house at the ground floor. These dosimeters were exposed to radon for three months (November, December 2012 and January 2013). Fig.(1) show us the map of study area.

\subsection{Calibration of CR-39 detectors}

Four detectors were exposed to a known activity of 226Ra (Radium is used to produce radon a single gram of radium-226 will produce 0.0001 milliliters of radon a day [8]. Then Radium is solid radon source) for a determined period of time. Then these detectors were treated by chemical etching. The average numbers of tracks $/ \mathrm{cm} 2$ were calculated. These detectors were inserted in the same volume (chamber) of the investigated sample, so they considered as a calibration standard or calibration constant (factor) $\mathrm{K}$ were determined by dividing the track density by the total exposure of radon source as in the following equation [9].

$$
K=\left(\frac{C_{R} T_{R}}{\rho_{R}}\right)
$$

Where $C_{R}$, Concentration of activity of 226Ra (solid radon source) $\mathrm{Bq} / \mathrm{m} 3 ; \rho_{\mathrm{R}}$, Track density (number of tracks $/ \mathrm{m} 2$ ) in detectors exposed to 226Ra; $T_{R}$, Exposure time (in days) of detectors exposed to 226Ra, then the radon concentration becomes as follows :

$$
C_{R n}\left(\frac{B q}{m^{3}}\right)=K_{1,2,3,4}\left(\frac{\rho_{R n}}{T_{R n}}\right)
$$

Where $\quad K_{1,2,3,4}=\frac{K_{1}+K_{2}+K_{3}+K_{4}}{4}, \rho_{\text {Rn }}=\frac{\mathrm{N}(\text { tracks })}{\mathrm{S}\left(\mathrm{m}^{2}\right) \mathrm{t}(\text { sec. })}$ (The track density $\left(\rho_{\mathrm{Rn}}\right)$ is the number of tracks recorded on the SSNTD (CR-39 detector) divided by the surface area $(\mathrm{S})$ and by the irradiation time $(\mathrm{t}))$. The calibration factor $(\mathrm{K})$ is determined, where four CR-39 detectors are exposed to 226Ra (Radium Source) of activity concentration $1000 \mathrm{~Bq} / \mathrm{m} 3$ (from factory) for 90 days. The calibration process for detectors used in this research was carried out at the nuclear laboratory at physics department in The College of science in Thi Qar University. The average calibration factor $\mathrm{K}$ is $0.00296[\mathrm{~Bq} / \mathrm{m} 3$ day/tracks $/ \mathrm{m} 2]$, with standard deviation $9.97 \%$. Substituting calibration constant (Factor) in eq. (4) we get:

$$
\mathrm{C}_{\mathrm{Rn}}\left(\frac{\mathrm{Bq}}{\mathrm{m}^{3}}\right)=0.00296\left(\frac{\rho_{\mathrm{Rn}}}{\mathrm{T}_{\mathrm{Rn}}}\right)
$$




\section{Measurements and calculation}

The CR-39 (Columbia Resin-39) is the trade name of the thermo set plastic which is a polymeric form of poly-allyl diglycol carbonate (PADC) Tastrak. It's simple formula is a $(\mathrm{C} 12 \mathrm{H} 18 \mathrm{O} 7) n$ with a density of $1.31 \mathrm{~g} \mathrm{~cm}-3$. These detectors are manufactured by TASL (Track Analysis Systems Ltd, Bristol, UK). They are square in shape, $1.0 \times 1.0 \mathrm{~cm}$ in size and $0.5 \mathrm{~cm}$ thickness used in present work, to measure the concentration of the radioactive radon gas $\mathrm{Rn}-222$ indoor for 12 deferent cities in Thi Qar province. 176 detectors were prepared and were distributed in the chosen locations. Each detector consist of assembly system include CR-39 detector enclosed in small plastic chamber (10 $\mathrm{cm}$ height, $9 \mathrm{~cm}$ diameter) and an arm to install the detector assembly on the wall, Fig.(2a). After 90 days the CR-39 detectors were collected from various cities of Thi Qar province. The CR-39 detectors were visualized in a solution of $6.25 \mathrm{~N}$ $\mathrm{NaOH}$ for $7 \mathrm{hr}$ at $70 \mathrm{Co}$, washed in clean water for 10 minutes and then with distilled water. After a few minutes of drying in air, the detectors were ready for track counting. The tracks on the CR-39 were counted per unit area in each detector using computerized optical microscope type MICROS Crocus II MCX100LCD made by MICROS Produktions, Vienna, AUSTRIA. The average calibration factor K for CR-39 detectors is $0.00296[\mathrm{~Bq} / \mathrm{m} 3$ day/tracks $/ \mathrm{m} 2]$, with standard deviation $9.97 \%$ determined in the present work.

\section{Results and Discussion}

The measurements of $222 \mathrm{Rn}$ concentration were performed for a period of 3 months from November 2012 to January 2013. The dosimeter at each house was installed using holder arm at bedroom with approximately 1.8 meters from the floor (breathing zone) and 0.3 meter from the wall as shown in Fig (2b). After the 3-month period of exposure, 117 detectors from 176 were retrieved; other detectors are missing or damaged As a result of messes of some occupants in these detectors, because of lack of awareness of the health hazard posed by indoor radon, table (1). The present survey was limited to 176 houses chosen randomly from many houses in these cities because of the limited number of detectors that we had and also due to the difficulty in placing the detectors in various houses. The track densities found on the analyzed NTDs were converted into radon concentrations
$(\mathrm{Bq} / \mathrm{m} 3)$ using eq.(5) for the utilized radon dosimeter. The results for 117 houses were obtained, table (2). The variation of radon concentration in the 117 houses surveyed are shown in Fig.(2). This variation in concentration between cities because of radon concentrations in dwellings depend on meteorological and geological conditions, lifestyle, construction materials, and ventilation. The arithmetic mean, standard deviation, and range of indoor 222Rn concentration in Thi Qar province houses were 66.898, 48.55 , and $16.3-280.1 \mathrm{~Bq} / \mathrm{m} 3$, respectively.. All of the houses surveyed had indoor radon levels within permissible level when ICRP1993 recommended limit of 600 Bqm-3 was used. Few houses had higher radon levels if NRPB (Health Protection agency) UK and US. (environmental protection agency) EPA limits of 200 and $148 \mathrm{~Bq} \mathrm{~m}-3$ were used. In The present survey the annual effective dose Eaed (mSvyr-1) to the occupants is estimated corresponding to average radon concentration in each city using eq.(2) shown in table (3) and Fig.(3).

\section{Conclusion}

From our findings we can conclude that the most of indoor levels, as expected, were well below the US EPA limit of $148 \mathrm{~Bq} / \mathrm{m} 3$, just 4 houses (3.4\%) of 117 monitored shown concentration levels above limit, but the average indoor radon concentration in all cities are below the US EPA recommendation limit. The majority of our estimates for indoor radon are within the normal risk level. However, Al Fajir, Al Qulah, Al Nasir, AlGharaf, Al Nasiriyah, Suq Al Shiukh, Al Bateha and Al Aslah fell within normal risk while Al Fuhood, Al Gibiesh, Al Rifa'ay and Al Shatrah can be classified as higher than normal risk corresponding to average radon concentration in each city. Furthermore smoking increased the risk of death from radon-induced cancer. Our data suggest that increased attention needs to be paid to exposure to radon and the associated health risks in order to preserve public health and reduce the incidence of cancer.

\section{Acknowledgment}

I would like to thank a number of people who have helped and encouraged during my research specially Eng. Muwaffaq M. Jalood and all the student of 4th stage (2012/2013) in Physics department. I would also like to thank the residents living in the selected houses who willingly helped in the placement of the detectors in their houses. 
Table (1): Number of detectors distributed, collected and missing or Damaged in different cities of Thi Qar province.

\begin{tabular}{|c|c|c|c|}
\hline $\begin{array}{l}\text { Location* } \\
\text { (cities })\end{array}$ & $\begin{array}{c}\text { No. of detectors } \\
\text { distributed }\end{array}$ & $\begin{array}{c}\text { No. of detectors } \\
\text { collected* }\end{array}$ & $\begin{array}{c}\text { No. of detectors } \\
\text { missing }\end{array}$ \\
\hline Faj & 20 & 11 & 9 \\
\hline Qul & 10 & 7 & 3 \\
\hline Rif & 20 & 13 & 7 \\
\hline Nsr & 6 & 4 & 2 \\
\hline Sha & 20 & 18 & 2 \\
\hline Gha & 10 & 8 & 2 \\
\hline Nas & 20 & 14 & 6 \\
\hline Suq & 20 & 12 & 8 \\
\hline Bat & 10 & 5 & 5 \\
\hline Fuh & 10 & 6 & 4 \\
\hline Asl & 10 & 6 & 4 \\
\hline Gib & 20 & 13 & 7 \\
\hline $\begin{array}{c}\text { Total } \\
\text { detectors }\end{array}$ & 176 & 117 & 59 \\
\hline
\end{tabular}

* No. of detectors completely valid for measurements.

Table (2): Indoor radon concentrations and standard deviation in houses of 12 city in Thi Qar province

\begin{tabular}{|c|c|c|c|}
\hline $\begin{array}{l}\text { Location } \\
\text { (Cities) }\end{array}$ & $\begin{array}{l}\text { Radon concentration }\left(\mathrm{C}_{\mathrm{Rn}}\right) \\
\mathrm{Bq} / \mathrm{m}^{3}\end{array}$ & $\begin{array}{l}\text { Average Con.* } \\
\mathrm{Bq} / \mathrm{m}^{3}\end{array}$ & $\begin{array}{l}\text { Std.dev } \\
\text { SD }\end{array}$ \\
\hline Faj & $\begin{array}{l}21 \cdot 5,21 \cdot 8,23 \cdot 0,41 \cdot 9,28 \cdot 4,25 \cdot 2,26.3, \\
36.2,31 \cdot 6,68 \cdot 1,88.4\end{array}$ & 37.49 & 20.576 \\
\hline Qul & $\begin{array}{l}26.8,38.9,34.5,50.0,19.3,66.2, \\
23.8\end{array}$ & 37.07 & 15.22 \\
\hline Rif & $\begin{array}{l}48.0,39.6,67.3,27.2,69.8,38.5, \\
124.6,76.7,98.4,187.9,116.3,98.1, \\
214.5\end{array}$ & 92.838 & 54.77 \\
\hline Nsr & $40.6,33.8,28.0,26.2$ & 32.15 & 5.63 \\
\hline Sha & $\begin{array}{l}25.4,36.5,109.2,52.4,112.6,18.3, \\
102.7,196.2,280.1,133.5,94.2,66.6, \\
33.8,44.1,178.5,78.2,43.9,31.8\end{array}$ & 89.84 & 64.78 \\
\hline Gha & $\begin{array}{l}18.2,19.4,28.4,25.2,54.3,30.7,26.8, \\
20.7\end{array}$ & 27.96 & 10.79 \\
\hline Nas & $\begin{array}{l}37.1,68.0,81.4,62.3,53.1,71.6,64.4, \\
76.5,78.2,38.6,46.1,40.8,42.3,50.7\end{array}$ & 57.93 & 15.15 \\
\hline Suq & $\begin{array}{l}64.5,61.3,76.7,66.1,78.2,92.1,81.0, \\
77.3,54.4,52.2,45.4,48.7\end{array}$ & 66.48 & 14.04 \\
\hline Bat & $19.3,26.7,31.3,27.8,23.2$ & 25.66 & 4.1 \\
\hline Fuh & $68.5,88.6,194.3,153 \cdot 4,104.7,72.3$ & 113.63 & 45.71 \\
\hline Asl & $43.9,29.4,38.4,66.3,33.8,40.13$ & 41.988 & 11.80 \\
\hline Gib & $\begin{array}{l}65.1,96.4,55.8,80.3,89.4,54.1,76.0, \\
139.3,128.5,248.8,91.5,107.4\end{array}$ & 102.71 & 50.74 \\
\hline
\end{tabular}

Con ${ }^{*}=$ Concentration
Table (3): Average indoor radon concentration and calculated values of annual effective dose $\left(\mathrm{D}_{\text {aed }}\right)$ for 12 selected City in Thi Qar Province.

\begin{tabular}{|l|c|c|c|}
\hline $\begin{array}{l}\text { Location } \\
\text { (cities) }\end{array}$ & $\begin{array}{c}\text { Average Con. } \\
\left(\mathrm{Bq} / \mathrm{m}^{3}\right)\end{array}$ & $\begin{array}{c}\text { Dose Rate } \\
(\mathrm{nSv} / \mathrm{h})\end{array}$ & $\begin{array}{c}\text { Annual Effective } \\
\text { Dose }\left(\mathrm{D}_{\mathrm{as}}\right) \\
{[\mathrm{mSv} / \mathrm{y}]}\end{array}$ \\
\hline Faj & 37.49 & 211.9 & 1.300 \\
\hline Qul & 37.07 & 209.7 & 1.285 \\
\hline Rif & 92.83 & 524.6 & 3.220 \\
\hline Nsr & 32.15 & 181.7 & 1.115 \\
\hline Sha & 89.84 & 513.7 & 3.152 \\
\hline Gha & 27.96 & 158.2 & 0.963 \\
\hline Nas & 57.93 & 327.8 & 2.009 \\
\hline Suq & 66.48 & 375.9 & 2.306 \\
\hline Bat & 25.66 & 145.0 & 0.890 \\
\hline Fuh & 113.63 & 713.4 & 3.941 \\
\hline Asl & 41.98 & 236.8 & 1.455 \\
\hline Gib & 102.71 & 580.5 & 3.562 \\
\hline
\end{tabular}

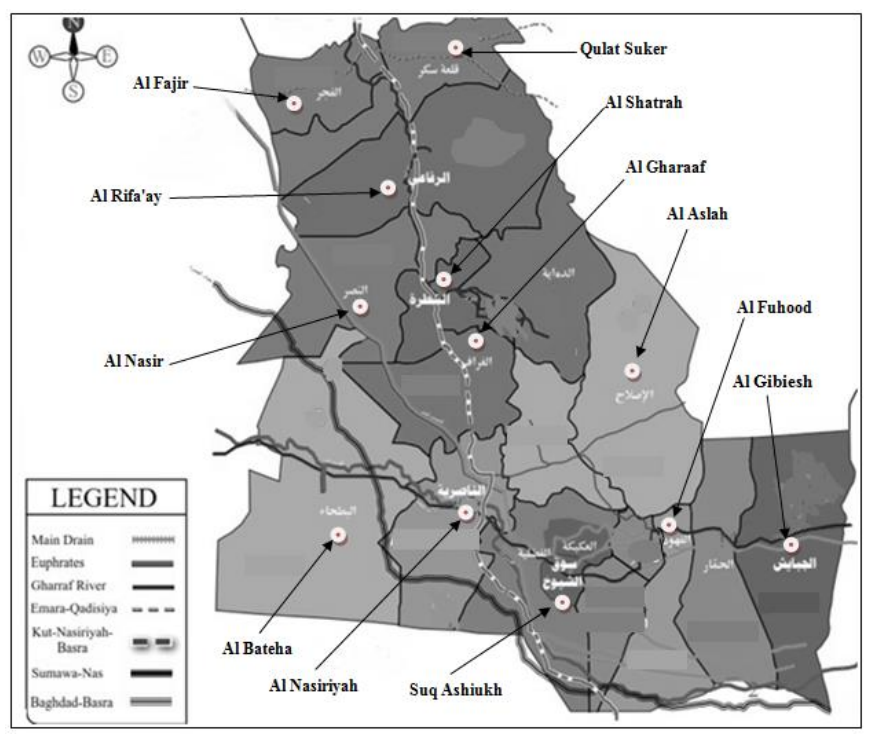

Fig.(1): The location of 12 cities in Thi Qar Province (Study area). 


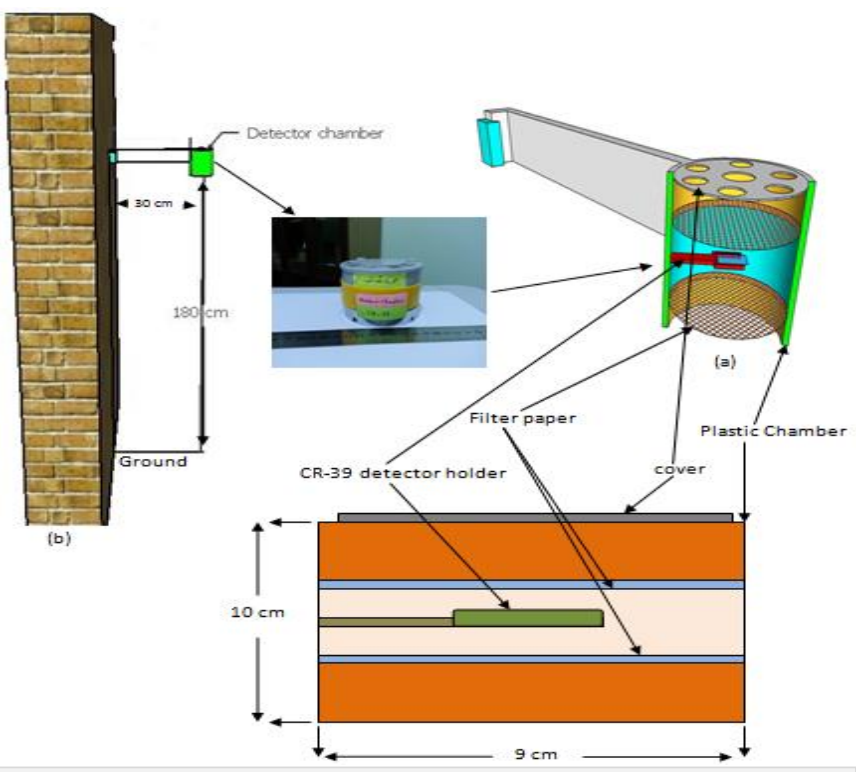

Fig.(2): Measurement technique used in the present work (a) radon chamber structure, (b) detector installation position in the house,

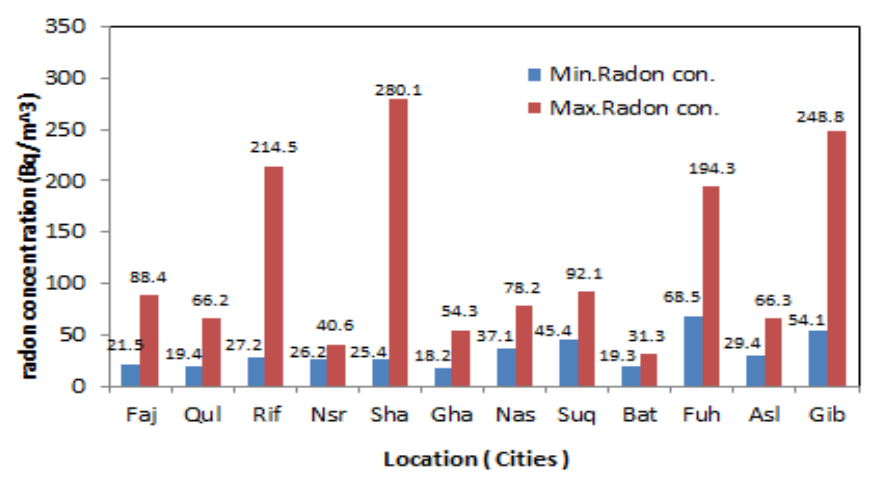

Fig.(3): Maximum and minimum of Indoor radon concentration $\left(\mathrm{Bq} / \mathrm{m}^{3}\right)$ for 12 selected city in Thi Qar province.

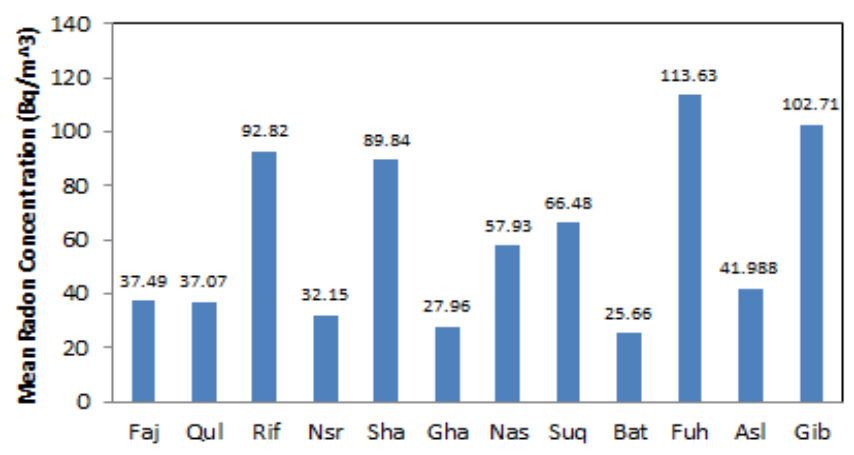

Fig.(4): Mean indoor radon concentration $\left(\mathrm{Bq} / \mathrm{m}^{3}\right)$ for 12 selected city in Thi Qar province .

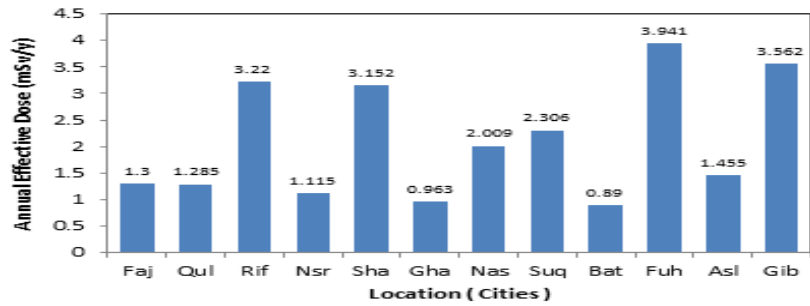

Fig.(5): Annual effective dose $\left(\mathrm{mSv} / \mathrm{m}^{3}\right)$ corresponding to mean indoor radon concentration in each city.

\section{References}

[1]. D. Saguatti, V. Tyzhnevyi, G. Giacomini, "Alpha-particle monitoring systems based on a BJT detector on high-resistivity silicon," 7th Conference on PhD Research in Microelectronics and Electronics, PRIME 2011 (Trento), (2011) .

[2]. M.Tufail, M. Amin, W. Akhtar, H. A. Khan, A. A. Qureshi and Manzoor, "Radon concentration in some houses of Islamabad and Rawalpindi, Pakistan", Nucl. Tracks Radiat. Meas., Vol. 19, No. 1-4, (1991) PP 29-430 .

[3]. F. Medici and L. Rybach, "Measurements of indoor radon Concentration and assessment of radiation exposure" Journal of Applied Geophysics, Vol. 31, No.1-4, Feb. (1994), pp 153-163 .

[4]. EPA 402-R-92-004. Washington, D.C: U.S. Government Printing Office; 1992b. United States Environmental Protection Agency. Indoor radon and radon decay product measurement devise protocols.

[5]. Oikawa S, Kanno N, Sanada T, Abukawa J Higuchi H. A survey of indoor workplace radon concentration in Japan. J Environ Radio act. No.87,(2006),pp 239-45.

[6]. UNSCEAR. Sources and Effects of Ionizing Radiation. United Nations Scientific Committee on Effects of Atomic Radiation. UNSCEAR 2000

Report to the General Assembly, with scientific annexes.2000; vol: 1

[7]. ICRP (International Commission on Radiological Protection). Protection Against radon-222 at home and at work. Pergamon Press, Oxford, 1993(ICRP Publication 65).

[8] .EPA (Environmental Protection Agency)"Radon Reference Manual",Office of Radiation Programs Washington DC 20460, EPA 520/1-87-20, September 1987.

[9]. NCRP (National Council on Radiation Protection and Measurements)"Measurement of Radon and Daughters in Air"NCRPT No.97, Bethesda, (M.D.) U.S.A.November 15, 1988. 